\title{
RELATIONSHIP BETWEEN C- REACTIVE PROTEIN/ALBUMIN RATIO AND CORONARY ARTERY DISEASE SEVERITY IN PATIENTS WITH STABLE ANGINA
}

\author{
By \\ Mohamed Nasr Ads, Abd El-Rahman Ibrahim Mohamed Ali, Abd El- \\ Alem Abd El-Alem Ali El-Gendy* and Mohamed Samy Abd El-Samea \\ Departments of Cardiology and Clinical Pathology*, Faculty of Medicine, Al-Azhar \\ University, Egypt \\ Corresponding author: Mohamed Nasr ads Department of Cardiology, Mahalla \\ Cardiology Center, Mahalla, Egypt
}

Phone: +201006209313, E-mail: dr_ads2010@yahoo.com

\begin{abstract}
Background: CAD is the largest contributor of cardiovascular diseases (CVDs) and mortality rate is due in prevalence to atherosclerosis. Syntax score (SS), which is an angiographic tool used in grading the complexity of coronary artery disease (CAD), has a prognostic importance in coronary artery disease (CAD) and provides important information regarding selection of revascularization strategy.

Objective: To assess the relationship between $\mathrm{C}$ reactive protein/albumin ratio (CAR), severity of coronary atherosclerosis assessed by the syntax score (SS) in patients with stable coronary artery disease.

Patients and Methods: This study was a prospective cohort study conducted on 100 patients divided into two equal groups according Syntax score. All patients underwent elective percutaneous coronary angiography, and have the following: hemoglobin levels, serum creatinine, serum cholesterol, serum albumin, C- reactive protein, resting 12-lead electrocardiography and Doppler - echocardiography.

Results: C-reactive protein/albumin ratio was significantly higher in patients with intermediate-high SS group. In multivariate regression analysis, CAR remained an independent predictor of intermediate-high SS group together with serum Cholesterol, HDL and LDL.

Conclusion: C-reactive protein/albumin ratio was more tightly associated with the complexity and severity of $\mathrm{CAD}$, and was found to be an independent predictor for intermediate-high SS group.

Key words: C-reactive protein/albumin ratio, Syntax score, coronary angiography.

\section{INTRODUCTION}

Coronary artery disease (CAD), the leading cause of mortality worldwide, places a serious economic burden on healthcare systems (Karabăg et al., 2018). It is mainly due to atherosclerosis (Michelsen et al., 2016). Inflammation

progression of atherosclerosis (Poddar et al., 2016). Serum albumin has many physiological properties, including antiinflammatory, antioxidant and antiplatelet aggregation activity. It also plays an essential role in the fluid exchange across the capillary membrane (Adach and Olas, 2020).
\end{abstract} plays a role in pathogenesis of onset and 
In the more specific context of cardiovascular diseases, serum albumin is independently associated with the development of a variety of deleterious conditions such as coronary artery disease, heart failure, atrial fibrillation and stroke (Wu et al., 2018).

Current data regarding the prognosis in critical illnesses and malignancies suggest that $\mathrm{C}$ reactive protein/albumin ratio (CAR) reflects the balance between CRP and albumin levels and has prognostic significance based on systemic inflammation (Wu et al., 2018).

The syntax score (SS), which is an angiographic tool used in grading the complexity of CAD, is assessed according to the coronary anatomy and characteristics of the coronary lesion (Neumann et al., 2019).

Clinical studies have shown that SS has prognostic importance in CAD and provides important information regarding the selection of revascularization strategy (Franzone et al., 2016).

The relationship between CAR and severity and complexity of CAD is not yet known. Because CAD is an essential inflammatory disease, CAR could be associated with complexity of CAD as assessed by SS (Karabağ et al., 2018 and Kundu et al., 2018).

The aim of the present study was to assess the relationship between $C$ reactive protein/albumin ratio (CAR), and the severity of coronary atherosclerosis assessed by the syntax score (SS) in patients with stable coronary artery disease.

\section{PATIENTS AND METHODS}

Our study was a prospective cohort study carried one MAHALLA CARDIAC CENTER during the period from May 2017 to February 2020 included 100 randomly selected patients who were admitted to coronary care unit for elective coronary angiography divided into two equal groups:

- Group I: High-intermediate syntax scores.

- Group II: Low syntax score.

\section{Inclusion criteria:}

Patients with stable angina pectoris (SAP) who underwent coronary angiography for suspected CAD who aged above 18 years old were enrolled in our study.

\section{Exclusion criteria:}

History of coronary artery bypass graft surgery, percutaneous coronary intervention, history of malignancy, history of active infection, history of connective tissue disorder, history of liver disease (cirrhotic liver), or patients refusal.

All patients underwent complete history taking, Full clinical examination and cardiac assessment, Electrocardiogram (ECG), Doppler echocardiography, Laboratory investigations (hemoglobin level, serum creatinine, serum cholesterol, serum albumin, C- reactive protein and Creactive protein/albumin ratio), calculating syntax score and percutaneous coronary angiography. 


\section{Statistical Analysis:}

Data were analyzed using Statistical program for the Social Sciences (SPSS) version 23. Quantitative data were expressed as mean \pm standard deviation (SD). Qualitative data were expressed as frequency and percentage.

We used the following tests of significance: Independent-samples t-test, Mann Whitney $\mathrm{U}$ test, Chi-square $\left(\mathrm{X}^{2}\right)$ test. Receiver operating characteristic (ROC) curve analysis was used to identify optimal cut-off values and to calculate sensitivity, specificity, PPV (positive predictive value), NPV (negative predictive value).Statistical significance was assessed at $\mathrm{P}$ values less than 0.05 .

\section{RESULTS}

In group I, there were $54 \%$ diabetic patients while in group II there were $32 \%$ diabetic patients. There was a statistically significant difference between the groups, $\mathrm{P}$ value $<0.03$.

In group I, there were $66 \%$ hypertensive patients, while in group II there were $40 \%$ hypertensive patients. There was a statistically significant difference between the groups $(\mathrm{P}$ value $>0.01)$.
In group I, there was a $32 \%$ smoker patient, while in group II there was $44 \%$ smoker patients. There was a statistically non-significant difference between the groups ( $\mathrm{P}$ value $<0.05$ ).

Regarding Family history of CVD, in group I, there were $26 \%$ patients with positive history, while in group II there was a $28 \%$ patient with positive history. There was a statistically non-significant difference between the groups ( $\mathrm{P}$ value < 0.05 (Table 1).

Table (1): Comparison between cases with high-intermediate syntax scores versus those with low score as regard demographic characteristics

\begin{tabular}{|c|c|c|c|}
\hline Sarameters & $\begin{array}{c}\text { High-intermediate } \\
\text { syntax scores N=50 }\end{array}$ & $\begin{array}{c}\text { low syntax score } \\
\text { N=50 }\end{array}$ & p-value \\
\hline Age & $58.5 \pm 6.4$ & $56.02 \pm 6.33$ & $>0.05$ \\
\hline Gender & Male (54\%) & Male (40\%) & $>0.05$ \\
\cline { 2 - 3 } & Female (46\%) & Female (60\%) & $>0.05$ \\
\hline Smoking & $32 \%$ & $44 \%$ & $<0.03$ \\
\hline DM & $54 \%$ & $32 \%$ & $<0.01$ \\
\hline HTN & $66 \%$ & $40 \%$ & $>0.05$ \\
\hline $\begin{array}{c}\text { Family history of } \\
\text { CVD }\end{array}$ & $26 \%$ & $28 \%$ & \\
\hline
\end{tabular}

Serum Cholesterol, in group I, mean was $205.24 \pm 40.04$, while in group II the mean was $184 \pm 35.28$. The main difference between the groups was statistically significant with $\mathrm{P}$ value $=$
0.006. Serum LDL, in group I, mean was $110.7 \pm 36.6$, while in group II the mean was $92.12 \pm 16.82$. The main difference between the groups was statistically significant with $\mathrm{P}$ value $=0.002$. 
Serum HDL, in group I, mean was $54.36 \pm 9.42$, while in group II the mean was $48.22 \pm 8.92$. The main difference between the groups was statistically significant with $\mathrm{P}$ value $=0.001$. Regarding serum creatinine in group I, mean was $0.98 \pm 0.34$, while in group II the mean was $0.99 \pm 0.35$. The main difference between the groups was statistically non-significant with $\mathrm{P}$ value $=0.001$.

Regarding Syntax Score in group I, the mean was $33.98 \pm 6.56$, while in group II the mean was $12.36 \pm 5.6$. The main difference between the groups was statistically highly significant with $\mathrm{P}$ value $<0.001$.
CRP in group I, median was $0.47(0.21-$ $0.93)$, while in group II the median was $0.21(0.06-0.34)$. The main difference between the groups was statistically highly significant with $\mathrm{P}$ value $<0.001$. $\mathrm{Crp} / \mathrm{Alb}$ ratio, in group I, median was 12.7 (5.6-29.1), while in group II the median was 5.6 (1.8-8.4). The main difference between the groups was statistically highly significant with $\mathrm{P}$ value $<0.001$.

Regarding EF, in group I, the mean was $50.52 \pm 6.18$ while in group II the mean was $57.8 \pm 6.47$. The main difference between the groups was statistically highly significant with $\mathrm{P}$ value $<0.001$ (Table 2).

Table (2): Comparison between cases with high intermediate syntax scores versus those with low score as regard Results of investigations

\begin{tabular}{|c|c|c|c|}
\hline Score & $\begin{array}{l}\text { High intermediate } \\
\text { syntax scores }\end{array}$ & $\begin{array}{l}\text { Low syntax } \\
\text { score }\end{array}$ & p-value \\
\hline & $\mathrm{N}=50$ & $\mathrm{~N}=\mathbf{5 0}$ & \\
\hline S Cholesterol(mg/dl) & $205.24 \pm 40.04$ & $184 \pm 35.28$ & $<0.006$ \\
\hline $\mathrm{LDL}(\mathrm{mg} / \mathrm{dl})$ & $110.7 \pm 36.6$ & $92.12 \pm 16.82$ & $<0.002$ \\
\hline HDL(mg/dl) & $54.36 \pm 9.42$ & $48.22 \pm 8.92$ & $=0.001$ \\
\hline $\mathrm{Cr}(\mathrm{mg} / \mathrm{dl})$ & $0.98 \pm 0.34$ & $0.99 \pm 0.35$ & $>0.05$ \\
\hline $\mathrm{HGB}(\mathrm{g} / \mathrm{dl})$ & 13.4(9.6-13.7) & 13.7(7.5-15.9) & $>0.05$ \\
\hline \multirow{2}{*}{ Dominant Syst } & $\mathrm{Rt}(64 \%)$ & $\mathrm{Rt}(68 \%)$ & \multirow{2}{*}{$>0.05$} \\
\hline & $\operatorname{Lt}(36 \%)$ & $\mathrm{Lt}(32 \%)$ & \\
\hline Syntax Score & $33.98 \pm 6.56$ & $12.36 \pm 5.6$ & $<0.001$ \\
\hline $\mathrm{CRP}(\mathrm{mg} / \mathrm{l})$ & $0.47(0.21-0.93)$ & $0.21(0.06-0.34)$ & $<0.001$ \\
\hline $\mathrm{Alb}(\mathrm{g} / \mathrm{dl})$ & $3.5(2.9-4.9)$ & $3.7(3.2-4.4)$ & $>0.05$ \\
\hline CRP/Alb Ratio & $12.7(5.6-29.1)$ & $5.6(1.8-8.4)$ & $<0.001$ \\
\hline $\mathrm{EF}(\%)$ & $50.52 \pm 6.18$ & $57.8 \pm 6.47$ & $<0.001$ \\
\hline
\end{tabular}

A multivariate logistic regression model was performed to ascertain the effects of DM, HTN, cholesterol, LDL, HDL and CRP/Alb Ratio on the likelihood that participants in intermediate-high syntax score and showed statistically significant difference (Table 3). 
Table (3): Logistic regression analysis of intermediate-high syntax score

\begin{tabular}{|c|c|c|c|}
\hline Score & Odd ratio & $\mathbf{9 5 \%}$ C.I & P value \\
\hline DM(mg/dl) & 2.42 & $1.27-7.34$ & $<0.05$ \\
\hline HTN(mmHg) & 3.06 & $1.02-5.74$ & $=0.012$ \\
\hline S Cholestrol(mg/dl) & 1.016 & $1.004-1.02$ & $<0.01$ \\
\hline LDL(mg/dl) & 1.025 & $1.008-1.042$ & $=0.004$ \\
\hline HDL (mg/dl) & 0.931 & $0.89-0.974$ & $=0.002$ \\
\hline Crp/Alb Ratio & 3.7 & $1.92-7.13$ & $<0.001$ \\
\hline
\end{tabular}

Correlation between CRP/ Albumin ratio, CRP, Albumin showed statistically significant differences $(\mathrm{P}$ value $<0.001)$ with CRP/ Albumin ratio and CRP, while non-significant difference ( $\mathrm{P}$ value $>0.05$ ) with Albumin (Table 4).

Table (4): Correlation between CRP/Alb ratio, CRP, Alb and high syntax score

\begin{tabular}{|c|c|c|}
\hline Items & $\begin{array}{c}\text { Pearson correlation } \\
\text { coefficient(r) }\end{array}$ & P value \\
\hline CRP/Alb ratio & 0.662 & $<0.001$ \\
\hline CRP & 0.667 & $<0.001$ \\
\hline Alb & 0.005 & $>0.05$ \\
\hline
\end{tabular}

ROC curve analysis was done for prediction of high syntax score and found that $\mathrm{C}$-reactive protein/albumin ratio and
C-reactive protein was the best predictor of high syntax score (Table 5).

Table (5): Receiver-operating characteristic (ROC) curves for C-reactive protein/albumin ratio, C-reactive protein for high syntax score

\begin{tabular}{|c|c|c|c|c|c|c|c|}
\hline \multirow{2}{*}{$\begin{array}{c}\text { Item } \\
\text { assessed }\end{array}$} & \multicolumn{2}{|c|}{$\begin{array}{c}\text { 95\% Confidence } \\
\text { Interval }\end{array}$} & Cutoff & Sensitivity & Specificity & AUC & P value \\
\cline { 2 - 8 } & $\begin{array}{c}\text { Lower } \\
\text { Bound }\end{array}$ & $\begin{array}{c}\text { Upper } \\
\text { Bound }\end{array}$ & point & & & & \\
\hline CRP & 0.935 & 0.999 & 0.26 & $91 \%$ & $82 \%$ & 0.967 & $<0.001$ \\
\hline $\begin{array}{c}\text { Crp/Alb } \\
\text { Ratio }\end{array}$ & 0.947 & 1.000 & 7.2 & $93 \%$ & $85 \%$ & 0.974 & $<0.001$ \\
\hline
\end{tabular}

\section{DISCUSSION}

In our study as regarding the age, in group I the Mean age was 58.5 \pm 6.4 years, and group II mean age was $56.02 \pm 6.33$ years. The main difference between the groups was statistically non-significant. Regarding gender, group I there were 54\% males and group II there were $40 \%$ males with non-statistically significant difference between the two groups.
Yahagi et al. (2015) stated that most of the underlying systemic risk factors for coronary artery disease are similar between men and women. However, the impact of various risk factors is different between men and women, with smoking being a stronger risk in women than men, especially in younger women. Furthermore, the influence of the menopause is also unique and important in 
women: incidence of plaque rupture is higher in older women as compared to younger.

Our results showed a statistically significant difference in between the two groups as regarding DM and HTN with non-significant difference with the other risk factors.

A study by $O$ h et al. (2017) stated that hypertension was the most common comorbidity. Men were more common in the non-survivor group. A history of cancer was more common among nonsurvivors, whereas hypertension was more common among survivors, but with nonsignificant difference as regarding DM and other risk factors.

On the other hand, Suzuki et al. (2019) enrolled 204 patients (mean age, 72 years; male, 69\%) and found no significant difference in between all patients as regarding the risk factors.

In our study as regarding serum cholesterol, in group I, the mean was $205.24 \pm 40.04$, while in group II the mean was $184 \pm 35.28$ with statistically significant with $P$ value $=0.006$.

For serum LDL, in group I, the mean was $110.7 \pm 36.6$, while in group II the mean was $92.12 \pm 16.82$ with a statistically significant difference. for serum HDL, in group I, the mean was $54.36 \pm 9.42$ while in group II the mean was $48.22 \pm 8.92$ with a statistically significant difference.

Our results were concordant with Suzuki et al. (2019) which stated that there was a statistical significant difference as regarding total cholesterol and LDL, with non-significant difference as regard HDL. On contrary, Duman et al. (2019) stated that there is no statistically significant difference as regarding LDL and HDL.

Our results showed that Syntax Score, in group I, was $33.98 \pm 6.56$, while in group II the mean was $12.36 \pm 5.6$ with statistically significant difference, and for $\mathrm{CRP}$, in group I, the median was 0.47 (0.21-0.93), while in group II the median was $0.21 \quad(0.06-0.34)$ with statistically significant difference.

On a study by Karabağ et al. (2018), they stated patients with stabile angina pectoris, who underwent coronary angiography for suspected CAD, have a high significant difference as regarding CRP between the high and low SS groups. Also, Kayapinar et al. (2019) had the same results as regarding hs-CRP.

In our study, CAR, in group I, median was 12.7 (5.6-29.1), while in group II was 5.6 (1.8-8.4). The main difference between the groups was statistically significant. Our results showed a multivariate logistic regression model which was performed to ascertain the effects of DM, HTN, cholesterol, LDL, HDL and Crp/Alb ratio on the likelihood that participants in intermediate-high syntax score, and showed a statistically significant difference. The correlation between CRP/ Albumin ratio, CRP, Albumin and high syntax score showed statistically significant difference with $\mathrm{CRP} /$ Albumin ratio and CRP, while nonsignificant with Albumin.

Oh et al. (2017) stated that the relationship between albumin, CRP level, and SS were similar to that reported in previous trials. Merging albumin and CRP into a single index is demonstrated to be associated with poor prognosis in a variety of disorders including cancer and sepsis. 
Blood urea nitrogen, hemoglobin, albumin, sodium and hs-CRP values showed statistically significant associations with all-cause in-hospital mortality. After adjusting for these variables, the hs-CRP/albumin ratio still showed an association with all-cause inhospital mortality. Patients in the fourth quartile were 5.94 times more likely to die compared with those in the lowest quartile of the hs-CRP/albumin ratio. When the hs-CRP/albumin ratio was examined as a continuous variable, it still showed an association with all-cause in-hospital mortality.

Kurtul et al. (2016) assumed that increased CRP/albumin ratio indicates a higher inflammatory state and may be superior to CRP and albumin alone in determining the prevalence and severity of CAD . They also stated that elevated CAR levels in stable CAD patients were independent predictors of intermediatehigh SS group, and the predictive accuracy of CAR was better than CRP and albumin level, as per the comparison of the ROC curves.

A study by Kinoshita et al. (2015) indicated that CAR levels were significantly associated with SS and were independent predictors for intermediatehigh SS group in patients who had underwent coronary angiography due to SAP. Furthermore, the CAR predicted intermediate-high SS group more accurately than either CRP or SA alone.

\section{CONCLUSION}

C-reactive protein/albumin ratio was more tightly associated with the complexity and severity of CAD, and was found to be an independent predictor for intermediate-high SS group.

\section{REFERENCES}

1. Adach, W. and Olas, B. (2020): Carbon monoxide and its donors-their implications for medicine. Future Medicinal Chemistry, 11(1): 61-73.

2. Arques, S., (2018): Serum albumin and cardiovascular diseases: A comprehensive review of the literature. In Annales de cardiologie et d'angeiologie (Vol. 67, No. 2, pp. 82-90).

3. Duman, H., Çinier, G., Bakırcı, E.M., Duman, H., Şimşek, Z., Hamur, H., Değirmenci, H. and Emlek, N., (2019): Relationship between C-reactive protein to albumin ratio and thrombus burden in patients with acute coronary syndrome. Clinical and Applied Thrombosis/Hemostasis, 25: 10-40.

4. Franzone, A., Taniwaki, M., Rigamonti, F., Heg, D.H., Piccolo, R., Roffi, M., Tüller, D., Muller, O., Vuilliomenet, A., Cook, S. and Weilenmann, D., (2016): Angiographic complexity of coronary artery disease according to SYNTAX score and clinical outcomes after revascularisation with newergeneration drug-eluting stents: a substudy of the BIOSCIENCE trial. EuroIntervention, 12(5): e595-604.

5. Karabă̆, Y., Çă̆daş, M., Rencuzogullari, I., Karakoyun, S., Artaç, İ., İliş, D., Atalay, E., Yesin, M., Gürsoy, M.O. and Halil Tanboğa, I., (2018): Relationship between C- reactive protein/albumin ratio and coronary artery disease severity in patients with stable angina pectoris. Journal of clinical laboratory analysis, 32(7): e22457.

6. Kayapinar, O., Ozde, C. and Kaya, A., (2019): Relationship between the reciprocal change in inflammation-related biomarkers (Fibrinogen-to-Albumin and hsCRP-toAlbumin ratios) and the presence and severity of coronary slow flow. Clinical and Applied Thrombosis/Hemostasis, 25: 710-790.

7. Kinoshita, A., Onoda, H., Imai, N., Iwaku, A., Oishi, M., Tanaka, K., Fushiya, N., Koike, K., Nishino, H. and Matsushima, M., (2015): The C-reactive protein/albumin ratio, a novel inflammation-based prognostic 


\section{MOHAMED NASR ADS et al.,}

score, predicts outcomes in patients with hepatocellular carcinoma. Annals of Surgical Oncology, 22(3): 803-810.

8. Kundu, A., Sardar, P., O'Day, K., Chatterjee, S., Owan, T. and Abbott, J.D., (2018): SYNTAX score and outcomes of coronary revascularization in diabetic patients. Current Cardiology Reports, 20(5)28-35.

9. Kurtul, A., Murat, S.N., Yarlioglues, M., Duran, M., Ocek, A.H., Koseoglu, C., Celık, I.E., Kilic, A. and Aksoy, O., (2016): Usefulness of serum albumin concentration to predict high coronary SYNTAX score and inhospital mortality in patients with acute coronary syndrome. Angiology, 67(1): 34-40.

10. Michelsen, M.M., Mygind, N.D., Pena, A., Aziz, A., Frestad, D., Høst, N. and Prescott, E., (2016): Peripheral reactive hyperemia index and coronary microvascular function in women with no obstructive CAD: the iPOWER study. JACC: Cardiovascular Imaging, 9(4): 411-417.

11. Neumann, F.J., Sousa-Uva, M., Ahlsson, A., Alfonso, F., Banning, A.P., Benedetto, U., Byrne, R.A., Collet, J.P., Falk, V., Head, S.J. and Jüni, P., (2019): 2018 ESC/EACTS guidelines on myocardial revascularization. European Heart Journal, 40(2)::87-165.

12. Oh, J., Kim, S.H., Park, K.N., Oh, S.H., Kim, Y.M., Kim, H.J. and Youn, C.S., (2017): High-sensitivity C-reactive protein/albumin ratio as a predictor of inhospital mortality in older adults admitted to the emergency department. Clinical and
Experimental Emergency Medicine, 4(1): 1940.

13. Poddar, K.L., Modi, D.K., Wayangankar, S., Thakkar, B., Krishnaswamy, A., Kumari, M., Bdair, H., Sud, K., Parashar, A., Raza, M.Q. and Faruqui, R., (2016): Two-decade trends in the prevalence of atherosclerotic risk factors, coronary plaque morphology, and outcomes in adults aged $\leq$ 45 years undergoing percutaneous coronary intervention. The American Journal of Cardiology, 118(7): 939-943.

14. Suzuki, S., Hashizume, N., Kanzaki, Y., Maruyama, T., Kozuka, A. and Yahikozawa, K., (2019): Prognostic significance of serum albumin in patients with stable coronary artery disease treated by percutaneous coronary intervention. Plos one, 14(7): 450-540.

15. Wu, J., Tan, W., Chen, L., Huang, Z. and Mai, S., (2018): Clinicopathologic and prognostic significance of C-reactive protein/albumin ratio in patients with solid tumors: an updated systemic review and meta-analysis. Oncotarget, 9(17):13934.

16. Yahagi, K., Davis, H.R., Arbustini, E. and Virmani, R., (2015): Sex differences in coronary artery disease: pathological observations. Atherosclerosis, 239(1): 260267. 


\section{العلاقة ما بين البروتين المتفاعل سي الي نسبة الالبيومين

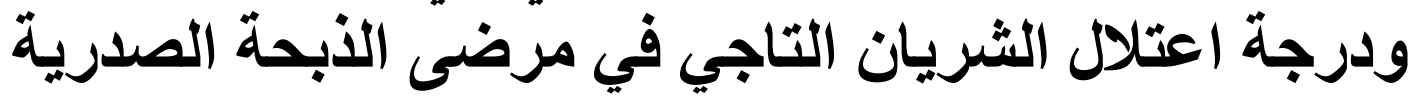 المستثرة}

محمد نصر عدس، عبد الرحمن إبراهيم محمد على، محمد سامي عبد السميع، عبد

$$
\text { *لعيم عبد العليم على الجندي }
$$

قسم أمراض القلب والأوعية الدموية و الباثولوجيا الاكلينيكية*، كلية الطب، جامعة الأزهر

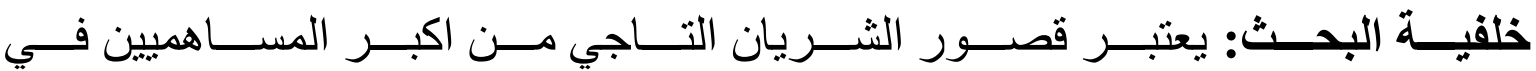

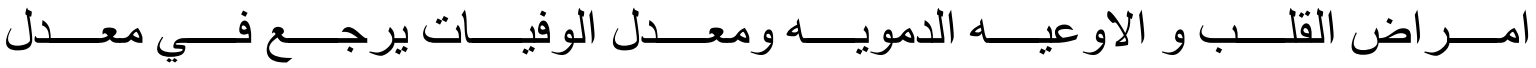
الانتشــــار إلـــى تصـــلب الثـــر ابين. و يعتبر حســـاب ســـينتاكس أداة أنجيو غر افيـــة

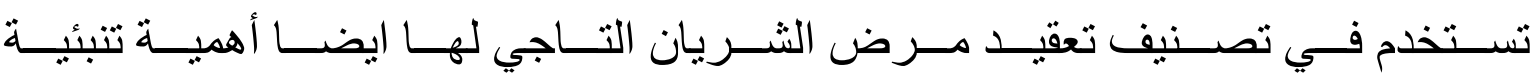

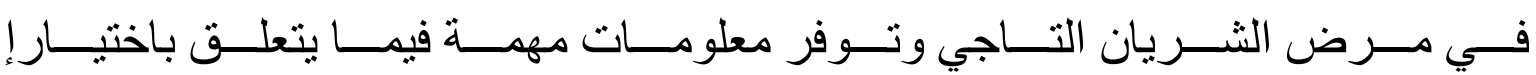

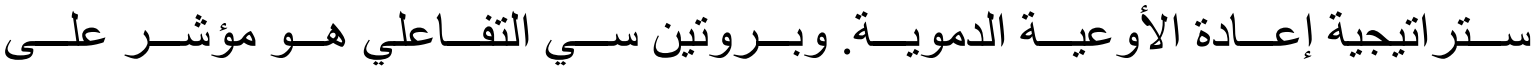

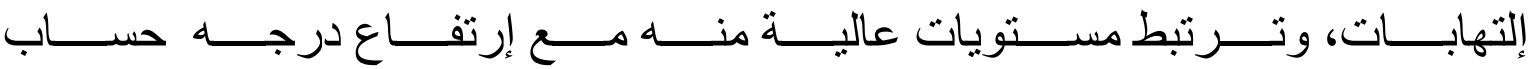
سبنتاكس.

الهـــف مــن البحــث: تقبـــم العلاقـة بــين نســبة البــروتين ســي التفــاعلي إلــي

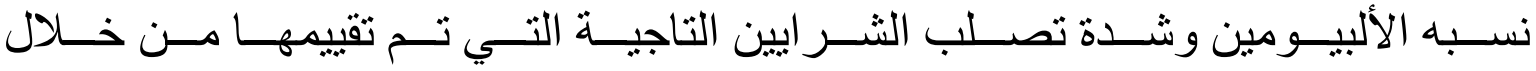

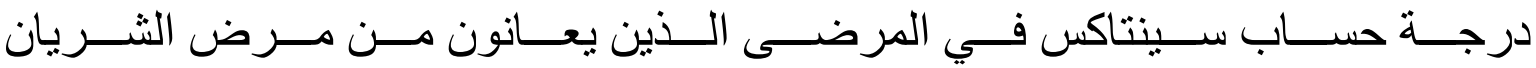
التاجي المستقر.

المرضـــي وطـــق البحــث: أجريـــت هــذه الدراســة علــى 100 مــريض مقســمة

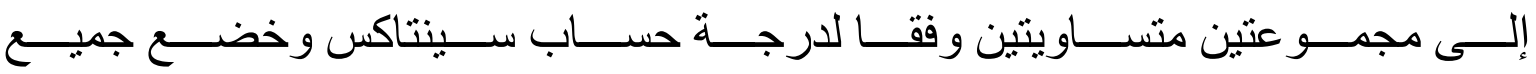

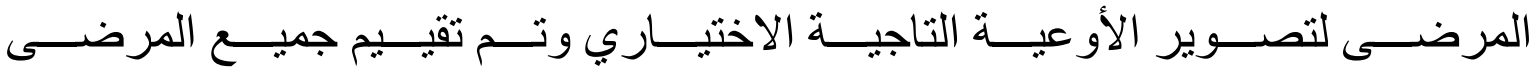

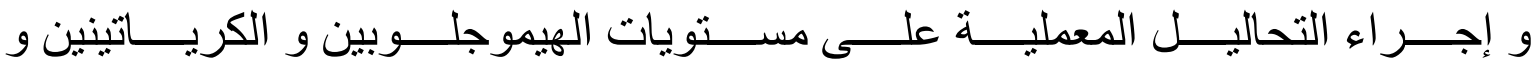

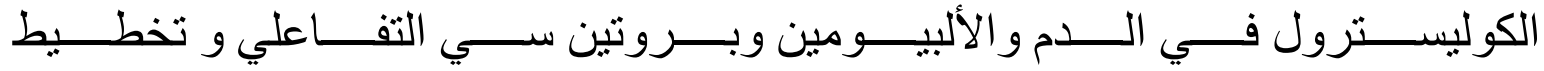
القلب الكهربائي دوبلروتخطيط صدى القلب. 


\section{MOHAMED NASR ADS et al.,}

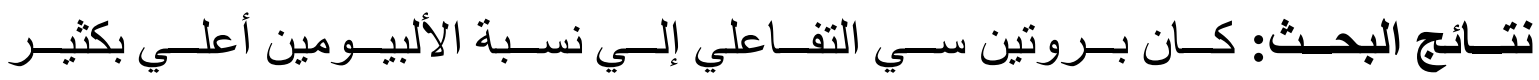

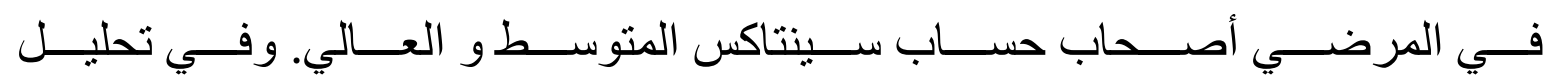

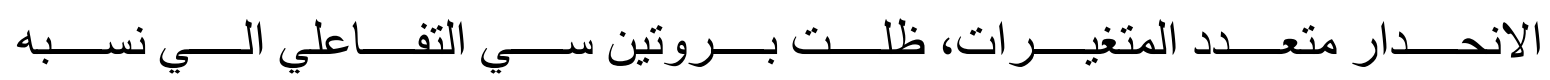

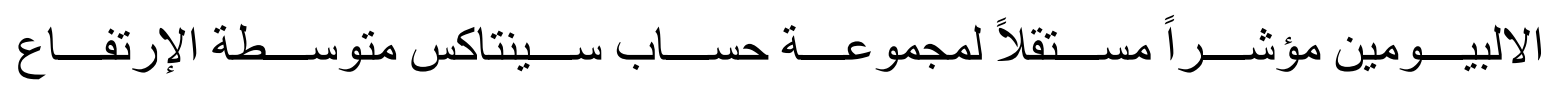
مع الكوليسترول في الدم و الكوليسترول الخفيف و المتكدث. موند.

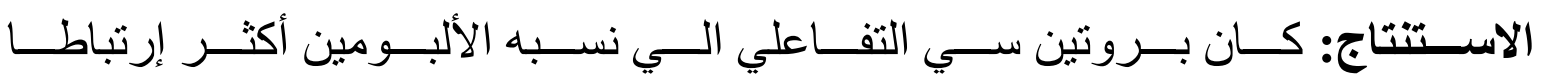

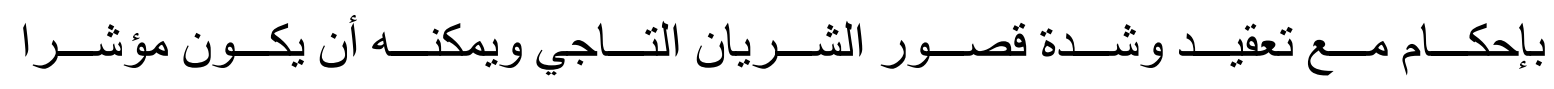
مستقلا لمجمو عة حساب سينتاكس المتوسطة و العالية. 